Original Research

\title{
Content and Species of Extracellular Phosphorus in Activated Sludge of Biological Phosphorus Removal Systems
}

\author{
Xiangyu Long ${ }^{1}$, Ran Tang1,2*, Chaoxin Xie ${ }^{1}$, Zhendong Fang ${ }^{1}$, Yongqin $\mathrm{Li}^{1}$ \\ ${ }^{1}$ Department of Military Installations, Army Logistic University of PLA, University Town, Chongqing, China \\ ${ }^{2}$ College of Chemistry and Chemical Engineering, Chongqing University of Science and Technology, \\ University Town, Chongqing, China
}

Received: 13 June 2018

Accepted: 15 October 2018

\begin{abstract}
Extracellular polymeric substances (EPS) contain a large amount of phosphorus, but the content of extracellular phosphorus in activated sludge and the decomposition of extracellular polyphosphate (polyP) in extraction process is still unclear. In this study, the extraction efficiencies of extracellular phosphorus using sonication, cation exchange resin (CER) and sonication-CER methods were investigated and compared, taking the aerobic sludge from four lab-scale A/O-SBR reactors at different temperatures and in different matrices as the objects. The sonication-CER method was an efficient and reliable method for extracting EPS and extracellular phosphorus, which could avoid the decomposition of extracellular polyP and the massive lysis of a bacterial cell. Importantly, utilizing CER with two successive alkaline washes was a key factor for efficiently extracting extracellular phosphorus. The extracellular phosphorus content of aerobic-activated sludge in 4 A/O-SBR reactors was $28.17 \sim 73.13 \mathrm{mg} \mathrm{P} / \mathrm{g} \mathrm{VSS}$, accounting for 59.6 74.1\% $\mathrm{TP}_{\text {sludge }}$. Thereby phosphorus of sludge floc was mainly located in EPS. Furthermore, polyP was the main species of extracellular phosphorus in EBPR sludge, which mainly existed in the inner layer of sludge floc. There was a close relationship between the content and species of extracellular phosphorus and the EBPR performance of activated sludge.
\end{abstract}

Keywords: Enhanced biological phosphorus removal; extracellular polymeric substances (EPS); extracellular phosphorus; cation exchange resin (CER) method; polyphosphate

\section{Introduction}

Phosphorus is recognized as one of the main factors for eutrophication in natural waters [1]. The enhanced biological phosphorus removal (EBPR) process is

*e-mail: tangranhncq@126.com an important approach to remove phosphorus in wastewater [2]. The EBPR process is mainly attributed to a group of selectively enriched heterotrophic bacteria, i.e., phosphorus-accumulating organisms (PAOs). PAOs, including denitrifying phosphorusaccumulating organisms (DPBs), can release phosphorus in the anaerobic phase and absorb phosphorus in the aerobic or anoxic phase. Thereby, anaerobic/aerobic phosphorus removal and denitrifying phosphorus 
removal are crucial approaches of EBPR [1-3]. However, the mechanism of phosphate release and adsorption of PAOs cannot explain all the phenomena of biological phosphorus removal, indicating that the theory of EBPR is not perfect [3]. Interestingly, extracellular polymeric substances (EPS) containing a large amount of phosphorus has been reported $[4,5]$, which provides a new perspective for improving the EBPR theory.

EPS are important components in biological aggregations $[5,6]$, of which the role in the EBPR process should not be neglected. Cloete et al. [7] has observed that $27 \sim 30 \%$ of phosphorus existed in EPS of the sludge floc based on an X-ray scanning electron microscope and energy-dispersive spectrometer. Borovec et al. [4] adopted the Ruttenberg method for chemical fractionation to evaluate the distribution of phosphorus in the benthic cyanobacterial mat (CBM), and reported that the phosphorus content of EPS was as high as $52 \%$ of the TP of CBM. Wang et al. [8] extracted EPS in EBPR granular sludge using a heating method, and showed that the phosphorus content of EPS was 30 45.4\% of the TP of sludge. Li et al. [9] and Zhang et al. $[10,11]$, however, extracted EPS using the CER method and found that the phosphorus content of EPS accounted for $9.61 \sim 9.97 \%$ and $6.6 \sim 10.5 \%$ of the TP of sludge, respectively. These extraction amounts of extracellular phosphorus were obviously different, mainly due to the different extraction methods and sources of sludge samples. Thus far, the exact roles of extracellular phosphorus in the EBPR process have not yet been clearly understood. To clarify the roles of extracellular phosphorus, the suitable extraction methods of extracellular phosphorus in activated sludge of EBPR should be investigated for ascertaining the content of extracellular phosphorus.

Polyphosphate (polyP) that is a key energy-storage substance in the EBPR process, was detected in EPS using ${ }^{31} \mathrm{P}$-nuclear magnetic resonance (NMR) [1012], indicating that EPS participated in the biological phosphorus-accumulation process. PolyP, a high-energy substance, is also easily decomposed [10]. Therefore, the decomposition of extracellular polyP in the process of extracting extracellular phosphorus should be avoided, which impacts the analysis results of extracellular phosphorus species. However, the influences of EPS extraction methods on the decomposition of extracellular polyP are still unclear.

The evaluation of the EPS extraction methods was mainly based on gaining the more extraction amount of EPS and avoiding chemical pollution and bacterial cell lysis, but not considering the greater extraction amount of extracellular phosphorus and the decomposition of extracellular polyP. Both sonication and CER methods are widely used to extract EPS [10, 13, 14], because of avoiding chemical pollution for extracted EPS. However, the influences of sonication and CER methods on the decomposition of extracellular polyP have not yet been reported. Moreover, these two methods have different action mechanisms, and if combining them, the extraction amount of extracellular phosphorus might be enhanced. In this study, based on discussing the influence of sonication and CER methods on the decomposition of polyP and avoiding significant bacterial cell lysis as a prerequisite, the method and procedure of combining sonication and CER (sonication-CER method) were investigated. In addition, the extraction extracellular phosphorus in the activated sludge at different temperatures and in different matrices with the three methods were compared in order to confirm the content of extracellular phosphorus. Finally, the relationship between the content and species of extracellular phosphorus and biological phosphorus removal performance of activated sludge was discussed.

\section{Materials and Methods}

\section{Activated Sludge Culture}

The seed sludge of four lab-scale A/O-SBR reactors was obtained from the $\mathrm{Ji}$ Guan Shi Wastewater Treatment Plant in Chongqing, China. The sludge of the reactors was fed with synthetic wastewater, which utilized sodium acetate or sodium propionate as the sole carbon source. COD: N: P of the synthetic wastewater was 100:5:5; the components are shown in Table S1 and

Table S1. The components of the synthetic wastewater.

\begin{tabular}{|c|c|c|c|}
\hline Components & Concentration $(\mathrm{g} / \mathrm{L})$ & Components of microelement & Concentration (mg/L) \\
\hline $\mathrm{C}_{2} \mathrm{H}_{3} \mathrm{NaO}_{2} \cdot 3 \mathrm{H}_{2} \mathrm{O}$ & 1.2300 & $\mathrm{FeSO}_{4} \cdot 7 \mathrm{H}_{2} \mathrm{O}$ & 4.1700 \\
\hline $\mathrm{C}_{3} \mathrm{H}_{5} \mathrm{NaO}_{2}$ & 1.3800 & $\mathrm{MnSO}_{4} \cdot \mathrm{H}_{2} \mathrm{O}$ & 0.1300 \\
\hline $\mathrm{NH}_{4} \mathrm{Cl}$ & 0.1433 & $\mathrm{ZnSO}_{4} \cdot 7 \mathrm{H}_{2} \mathrm{O}$ & 0.0840 \\
\hline $\mathrm{KH}_{2} \mathrm{PO}_{4}$ & 0.1650 & $\mathrm{CoCl}_{2} \cdot 6 \mathrm{H}_{2} \mathrm{O}$ & 0.0390 \\
\hline $\mathrm{MgSO}_{4} \cdot \mathrm{H}_{2} \mathrm{O}$ & 0.0200 & $\mathrm{CuSO}_{4} \cdot 5 \mathrm{H}_{2} \mathrm{O}$ & 0.0180 \\
\hline $\mathrm{CaCl}_{2}$ & 0.0068 & $\mathrm{KI}_{2} \mathrm{O}$ & 0.1080 \\
\hline $\mathrm{FeSO}_{4} \cdot 7 \mathrm{H}_{2} \mathrm{O}$ & 0.0043 & $\mathrm{H}_{3} \mathrm{BO}_{3}$ & 0.0900 \\
\hline
\end{tabular}


the $\mathrm{pH}$ was approximately 7.0. Instantaneous filling wastewater was adopted. The reactors had a working volume of $15 \mathrm{~L}$, and were operated for 2 cycles every day. Each cycle lasted for $12 \mathrm{hr}$, involving a 4-hr anaerobic period, 7-hr of aeration, 50-min settlement, $5 \mathrm{~min}$ of decanting, and $5 \mathrm{~min}$ of idling. The temperatures of four reactors were controlled at $20 \pm 1^{\circ} \mathrm{C}$ or $35 \pm 1^{\circ} \mathrm{C}$. The solid retention times (SRTs) were approximately 20 days, discharging the mixed liquid every day. The dissolved oxygen (DO) concentrations at the end of the aeration stage were $3.0-5.0 \mathrm{mg} / \mathrm{L}$, with regulating gas flow. The sludge samples were collected at the end of the aerobic stage.

\section{Method of Washing CER}

001×7 gel-type CER (20-40 mesh, Suqing, Jiangsu, China) was used to the CER and sonication-CER methods. The CER was washed by $8 \% \mathrm{NaCl}, 1 \mathrm{~mol} / \mathrm{L}$ $\mathrm{HCl}$ and $1 \mathrm{~mol} / \mathrm{L} \mathrm{NaOH}$ solution in turn, alternating $\mathrm{HCl}$ and $\mathrm{NaOH}$ solution for 3 times wash. Meanwhile, the CER was washed to neutral by pure water in each washing step. At the end of the wash process, two successive alkaline washes were key steps, after which the CER was washed to neutral to prepare for use.

\section{Extraction Methods of Extracellular Phosphorus}

\section{Sonication Method}

$21 \mathrm{kHz}$ sonication (JY90-II; Scientz Bioscience Co., Inc., Ningbo, China) was used to act on the $40 \mathrm{~mL}$ sludge washed by centrifugation. Subsequently, the sludge was centrifuged twice at $0 \pm 2^{\circ} \mathrm{C}$ and $43000 \times \mathrm{g}$, and the supernatant was designated as EPS containing extracellular phosphorus. The sonication probe area was $0.28 \mathrm{~cm}^{2}$, and the duty cycle of the sonication process was $50 \%$.

\section{Cation Exchange Resin (CER) Method}

The washed CER was used to process the $40 \mathrm{~mL}$ sludge washed by centrifugation, of which the additional amount was $80 \mathrm{~g}$ of $\mathrm{CER} / \mathrm{g} \mathrm{VSS}$. Then the CER was filter-separated using nylon mesh with a $250-\mu \mathrm{m}$ pore diameter. Finally, the filtered mixed liquid was centrifuged twice at $0 \pm 2^{\circ} \mathrm{C}$ and $43000 \times \mathrm{g}$, and the centrifugal supernatant was designated as EPS containing extracellular phosphorus.

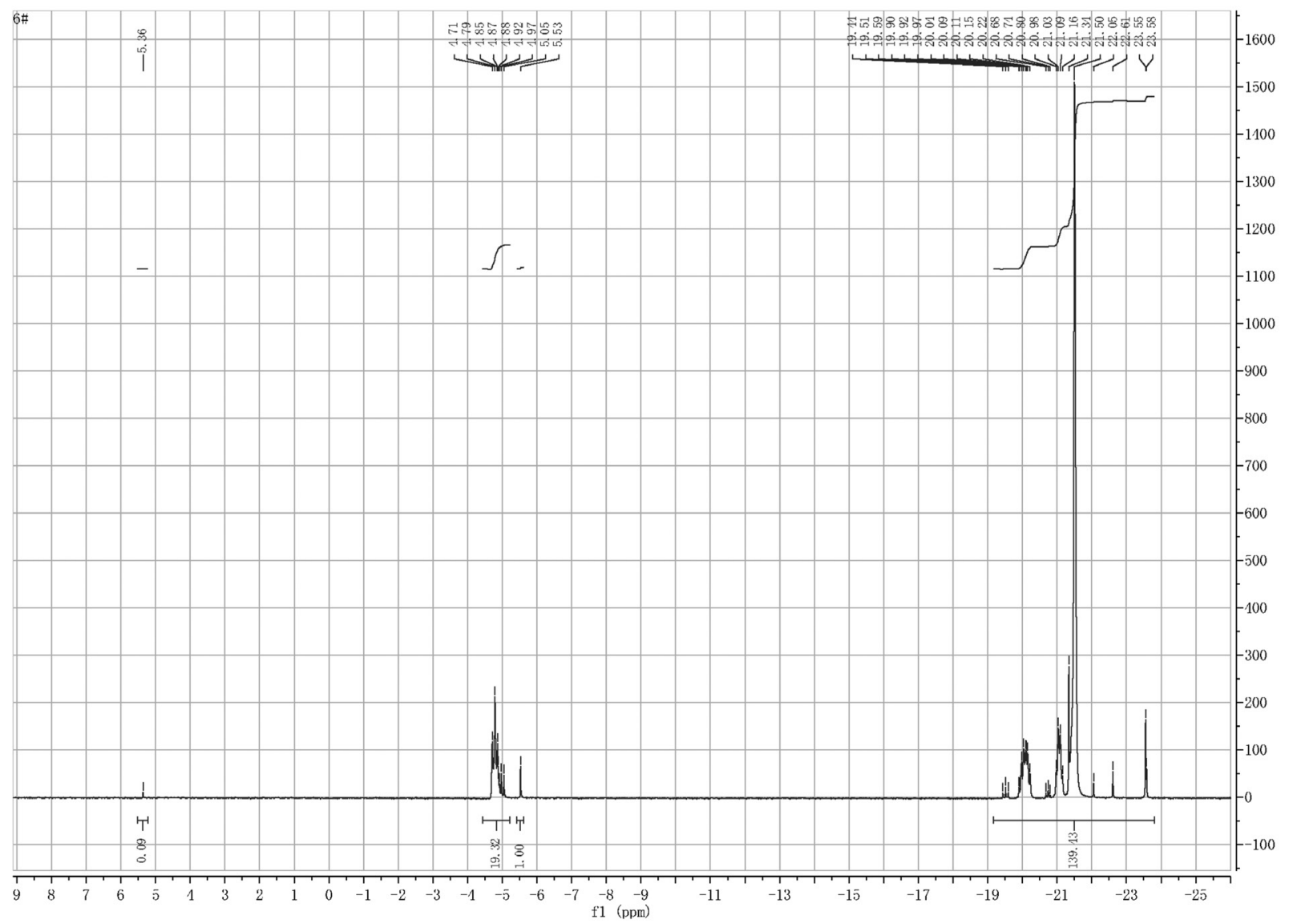

Fig. S1 ${ }^{31}$ P NMR spectroscopy of EPS simulation. 
Table 1. ${ }^{31} \mathrm{P}$ NMR chemical shifts and relative peak areas of phosphorus in EPS simulation dealing with sonication.

\begin{tabular}{|c|c|c|c|c|c|c|c|c|c|}
\hline \multirow[b]{2}{*}{$\begin{array}{l}\text { Extraction } \\
\text { conditions }\end{array}$} & \multicolumn{2}{|c|}{ OrthoP } & \multicolumn{2}{|c|}{ PyroP } & \multicolumn{2}{|c|}{ End groups of PolyP } & \multicolumn{2}{|c|}{ Middle groups of PolyP } & \multirow{2}{*}{$\begin{array}{l}\text { Average } \\
\text { chain } \\
\text { length } \\
\text { of polyP }\end{array}$} \\
\hline & $\begin{array}{c}\text { Chemical } \\
\text { shift } \\
(\mathrm{ppm})\end{array}$ & $\begin{array}{c}\text { Peak area } \\
(\%)\end{array}$ & $\begin{array}{c}\text { Chemical } \\
\text { shift } \\
(\mathrm{ppm})\end{array}$ & $\begin{array}{c}\text { Peak area } \\
(\%)\end{array}$ & $\begin{array}{c}\text { Chemical } \\
\text { shift } \\
(\mathrm{ppm})\end{array}$ & $\begin{array}{c}\text { Peak area } \\
(\%)\end{array}$ & $\begin{array}{c}\text { Chemical } \\
\text { shift } \\
(\mathrm{ppm})\end{array}$ & $\begin{array}{c}\text { Peak area } \\
(\%)\end{array}$ & \\
\hline Control & 5.36 & 0.04 & -5.51 & 0.59 & -4.71 & 12.21 & -19.43 & 87.16 & 16.28 \\
\hline $0.5 \mathrm{~W} / \mathrm{mL} 2 \mathrm{~min}$ & 5.36 & 0.05 & -5.53 & 0.59 & -4.79 & 12.31 & -19.52 & 87.05 & 16.15 \\
\hline $0.5 \mathrm{~W} / \mathrm{mL} 4 \mathrm{~min}$ & 5.36 & 0.05 & -5.52 & 0.60 & -4.85 & 12.33 & -19.58 & 87.02 & 16.12 \\
\hline $0.5 \mathrm{~W} / \mathrm{mL} 6 \mathrm{~min}$ & 5.36 & 0.03 & -5.53 & 0.64 & -4.92 & 12.23 & -19.89 & 87.10 & 16.25 \\
\hline $1 \mathrm{~W} / \mathrm{mL} 2 \mathrm{~min}$ & 5.36 & 0.02 & -5.52 & 0.64 & -4.96 & 12.14 & -19.98 & 87.20 & 16.36 \\
\hline $1 \mathrm{~W} / \mathrm{mL} 4 \mathrm{~min}$ & 5.36 & 0.13 & -5.52 & 0.65 & -5.05 & 12.15 & -21.03 & 87.07 & 16.33 \\
\hline $1 \mathrm{~W} / \mathrm{mL} 6 \mathrm{~min}$ & 5.36 & 0.06 & -5.51 & 0.69 & & 12.31 & -20.09 & 86.94 & 16.12 \\
\hline $2 \mathrm{~W} / \mathrm{mL} 2 \mathrm{~min}$ & 5.36 & 0.01 & -5.52 & 0.62 & & 12.26 & -20.97 & 87.11 & 16.21 \\
\hline $2 \mathrm{~W} / \mathrm{mL} 4 \mathrm{~min}$ & 5.36 & 0.12 & -5.53 & 0.63 & & 12.27 & -21.16 & 86.98 & 16.18 \\
\hline $2 \mathrm{~W} / \mathrm{mL} 6 \mathrm{~min}$ & 5.36 & 0.08 & -5.51 & 0.79 & & 12.43 & -21.50 & 86.70 & 15.95 \\
\hline $3 \mathrm{~W} / \mathrm{mL} 2 \mathrm{~min}$ & 5.36 & 0.13 & -5.52 & 0.63 & & 12.26 & -22.05 & 86.98 & 16.19 \\
\hline $3 \mathrm{~W} / \mathrm{mL} 4 \mathrm{~min}$ & 5.36 & 0.08 & -5.50 & 0.75 & & 12.48 & -22.61 & 86.69 & 15.90 \\
\hline $3 \mathrm{~W} / \mathrm{mL} 6 \mathrm{~min}$ & 5.36 & 0.06 & -5.52 & 0.65 & & 12.26 & $\begin{array}{l}-23.55 \\
-23.58\end{array}$ & 87.03 & 16.19 \\
\hline
\end{tabular}

\section{Sonication-CER Method}

The washed sludge was processed by sonication, then reacted with the CER to cation exchange.
Thereafter, the filtered mixed liquid was centrifuged twice at $0 \pm 2^{\circ} \mathrm{C}$ and $43000 \times \mathrm{g}$, and the centrifugal supernatant was designated as EPS containing extracellular phosphorus.

Table 2. ${ }^{31} \mathrm{P}$ NMR chemical shifts and relative peak areas of phosphorus in EPS simulation dealing with CER.

\begin{tabular}{|c|c|c|c|c|c|c|c|c|c|}
\hline \multirow[b]{2}{*}{$\begin{array}{l}\text { Extraction } \\
\text { conditions }\end{array}$} & \multicolumn{2}{|c|}{ OrthoP } & \multicolumn{2}{|c|}{ PyroP } & \multicolumn{2}{|c|}{ End groups of PolyP } & \multicolumn{2}{|c|}{ Middle groups of PolyP } & \multirow{2}{*}{$\begin{array}{l}\text { Average } \\
\text { chain } \\
\text { length } \\
\text { of polyP }\end{array}$} \\
\hline & $\begin{array}{c}\text { Chemical } \\
\text { shift } \\
(\mathrm{ppm})\end{array}$ & $\begin{array}{c}\text { Peak area } \\
(\%)\end{array}$ & $\begin{array}{c}\text { Chemical } \\
\text { shift } \\
(\mathrm{ppm})\end{array}$ & $\begin{array}{c}\text { Peak area } \\
(\%)\end{array}$ & $\begin{array}{c}\text { Chemical } \\
\text { shift } \\
(\mathrm{ppm})\end{array}$ & $\begin{array}{c}\text { Peak area } \\
(\%)\end{array}$ & $\begin{array}{c}\text { Chemical } \\
\text { shift } \\
(\mathrm{ppm})\end{array}$ & $\begin{array}{c}\text { Peak area } \\
(\%)\end{array}$ & \\
\hline Control & 5.36 & 0.04 & -5.51 & 0.59 & 4.71 & 12.21 & -19.43 & 87.16 & 16.28 \\
\hline $400 \mathrm{rpm} 10 \mathrm{~min}$ & 5.36 & 0.06 & -5.53 & 0.52 & -4.79 & 12.11 & -19.52 & 87.31 & 16.42 \\
\hline $400 \mathrm{rpm} 20 \mathrm{~min}$ & 5.36 & 0.15 & -5.52 & 0.59 & -4.85 & 12.00 & -19.58 & 87.26 & 16.54 \\
\hline $400 \mathrm{rpm} 30 \mathrm{~min}$ & 5.36 & 0.07 & -5.52 & 0.49 & -4.92 & 12.06 & -19.89 & 87.38 & 16.49 \\
\hline $400 \mathrm{rpm} 45 \mathrm{~min}$ & 5.36 & 0.32 & -5.54 & 0.38 & -4.96 & 12.14 & -19.98 & 87.16 & 16.36 \\
\hline $400 \mathrm{rpm} 60 \mathrm{~min}$ & 5.36 & 0.06 & -5.53 & 0.57 & -5.05 & 12.15 & -21.03 & 87.22 & 16.36 \\
\hline $550 \mathrm{rpm} 10 \mathrm{~min}$ & 5.36 & 0.06 & -5.53 & 0.63 & & 12.09 & -20.09 & 87.22 & 16.43 \\
\hline $550 \mathrm{rpm} 20 \mathrm{~min}$ & 5.36 & 0.01 & -5.53 & 0.62 & & 12.11 & -20.97 & 87.26 & 16.41 \\
\hline $550 \mathrm{rpm} 30 \mathrm{~min}$ & 5.37 & 0.06 & -5.51 & 0.63 & & 12.24 & -21.16 & 87.07 & 16.23 \\
\hline $550 \mathrm{rpm} 45 \mathrm{~min}$ & 5.36 & 0.05 & -5.52 & 0.57 & & 12.21 & -21.50 & 87.17 & 16.28 \\
\hline $550 \mathrm{rpm} 60 \mathrm{~min}$ & 5.36 & 0.06 & -5.52 & 0.59 & & 12.02 & -22.05 & 87.33 & 16.53 \\
\hline & & & & & & & -22.61 & & \\
\hline & & & & & & & -23.55 & & \\
\hline & & & & & & & -23.58 & & \\
\hline
\end{tabular}




\section{Cell Lysis Analysis}

The cell lysis rate during the extraction process was evaluated by glucose-6-phosphate-dehydrogenase (G6PD) activity [15, 16]. A Hoechst 33342/ propidium iodide (PI) double staining kit (Shanghai BestBio, Shanghai, China) was used to stain the bacterial cell after extracting EPS and extracellular phosphorus, then living and dead cells were observed by laser scanning confocal microscopy (LSCM; Leica TCS SP8, Oskar Barnack, Germany).

\section{${ }^{31} \mathrm{P}$ NMR Analysis}

The extracted EPS and extracellular phosphorus solution was lyophilized, and then stored at $-20^{\circ} \mathrm{C}$ before implementing ${ }^{31} \mathrm{P}$ NMR analysis. Approximately
$15 \mathrm{mg}$ of the freeze-dried samples were re-dissolved with $0.4 \mathrm{~mL}$ of $\mathrm{D}_{2} \mathrm{O}$ and $0.2 \mathrm{~mL}$ of $100 \mathrm{mmol} / \mathrm{L}$ EDTA solution. Before analysis, $0.2 \mathrm{~mL}$ of $2 \mathrm{~mol} / \mathrm{L} \mathrm{NaOH}$ solution was added. A $600 \mathrm{MHz}$ NMR spectrometer (Agilent Technologies, Santa Clara, USA) was used to analyze the ${ }^{31} \mathrm{P}$ NMR spectrum [10]. The number of scans was set at 256 (EPS extracts) or 64 (EPS simulation). The spectra were analyzed according to a previous study [17] and the data were determined by NMR data processing software (MestReNova v6.1.0-6224).

EPS simulation with high-temperature sterilization was used to study the features of polyP decomposition during the extraction process. The components of the EPS simulation were similar to EPS, in which polyP substance was sodium hexametaphosphate (SigmaAldrich, St. Louis, MO, USA).

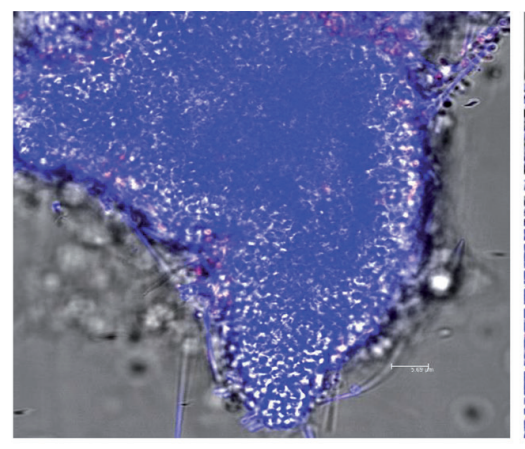

a
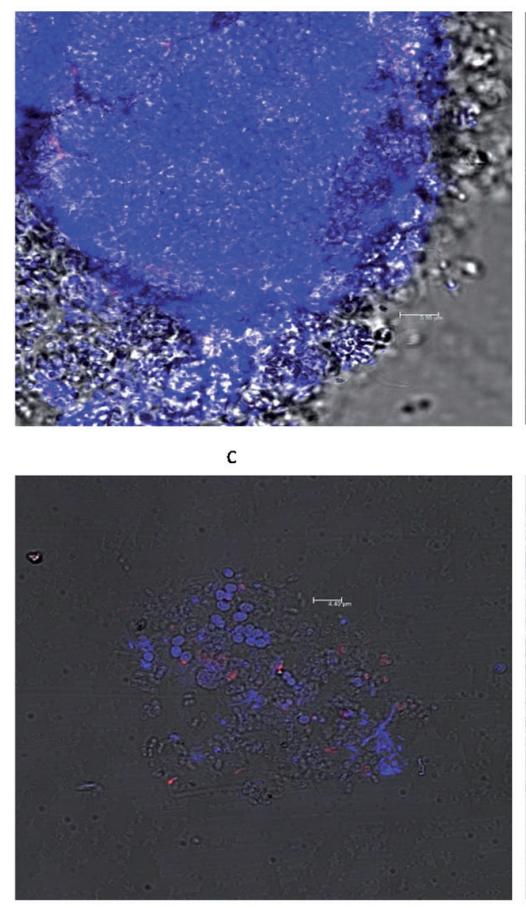

e

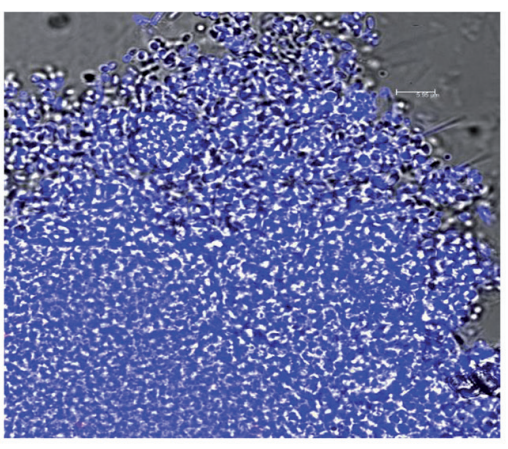

b

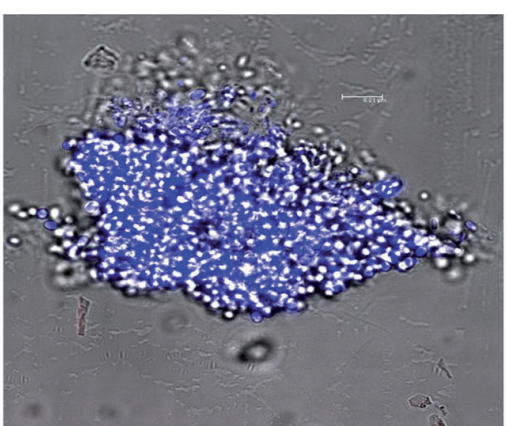

d

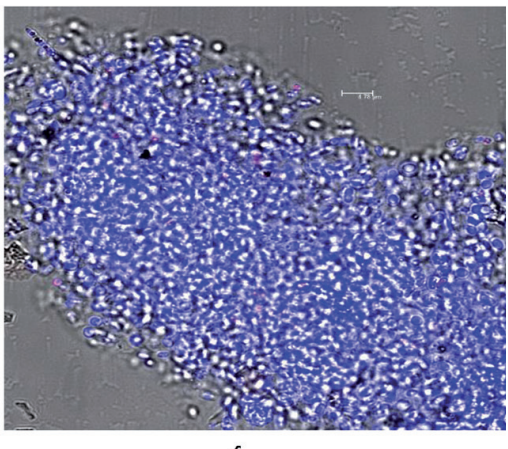

Fig. S2. Bacterial cell apoptosis / death induced by extraction process: a) Photo of confocal laser scanning microscope for raw sludge; b) Photo of confocal laser scanning microscope under the condition of sonication with the power density of $1 \mathrm{~W} / \mathrm{mL}$ for 6 min; c) Photo of confocal laser scanning microscope under the condition of sonication with the power density of $3 \mathrm{~W} / \mathrm{mL}$ for 6 min; d) Photo of confocal laser scanning microscope under the condition of CER with the stirring rate of 400rpm for $30 \mathrm{~min}$; e) Photo of confocal laser scanning microscope under the condition of CER with the stirring rate of 550rpm for $30 \mathrm{~min}$; f) Photo of confocal laser scanning microscope with sonication of $1 \mathrm{~W}$ per $\mathrm{mL}$ for $6 \mathrm{~min}$ and CER of $400 \mathrm{rpm}$ for $30 \mathrm{~min}$. 


\section{Other Chemical Analyses}

The total organic carbon (TOC) content of EPS extracts was measured using a TOC analyzer (multi N/C 2100S; Analytik Jena AG, Jena, Germany). The suspended solids (SSs), volatile suspended solids (VSSs), total extracellular phosphorus $\left(\mathrm{TP}_{\mathrm{EPS}}\right)$, and total phosphorus in sludge $\left(\mathrm{TP}_{\text {Sludge }}\right)$ were measured according to standard methods [18]. The morphology of microorganisms in the activated sludge was observed by a scanning electron microscope (MIRA 3 GMU/GMH; TESCAN, Brno, Czechoslovakia).

\section{Results and Discussion}

\section{PolyP Decomposition of the Extraction Process}

PolyP is a high-energy substance and prone to degradation [10]. To elucidate the species of extracellular phosphorus, polyP decomposition in the process of extracting EPS and extracellular phosphorus should be avoided. PolyP decomposition induced by sonication and CER methods were studied, taking EPS simulation as an object. EPS simulation dealt with sonication and CER methods, respectively, and then the phosphorus species were analyzed by ${ }^{31} \mathrm{P}$ NMR spectroscopy (Fig. S1). To avoid polyP decomposition/synthesis due to microbial metabolism, strict sterile operations were used in the process. In addition, the average chain length of polyP can be calculated from the ratio of peak area between the middle and end groups [19]. The average chain lengths of sodium hexametaphosphate in EPS simulation was approximately 16 . Importantly, the peak areas and the average chain lengths of the polyP were unchanged (Tables 1 and 2), when EPS simulation was processed by sonication method at a low frequency $(21 \mathrm{kHz})$ and low power density $(\leq 3 \mathrm{~W} / \mathrm{mL})$ or CER method with a short duration ( $\leq 60 \mathrm{~min})$ and medium-high speed $(\leq 550 \mathrm{rpm})$. The results indicated that PolyP decomposition was not induced by the sonication and CER methods with the above operating conditions, suggesting that analysis of species of extracellular phosphorus in the extracted EPS should be reliable.

\section{Cell Lysis of the Extraction Process}

Intracellular polymers and phosphorus are released with cell lysis, which would pollute EPS and extracellular phosphorus. Therefore, serious cell lysis should be avoided in the extraction process. Cell lysis induced by sonication, CER, or sonication-CER methods were analyzed, taking the activated sludge at the end of the aerobic stage of $20^{\circ} \mathrm{C}$ sodium acetate A/O-SBR reactor as an object. From Fig. 1a), with the increase of sonication power density and duration, the G6PD activity of EPS (G6PD ${ }_{\text {EPS }}$ ) was increased. Under the condition of sonication with the power density of $1 \mathrm{~W} / \mathrm{mL}$ for $6 \mathrm{~min}$ and the power density of $3 \mathrm{~W} / \mathrm{mL}$ for $2 \mathrm{~min}$, the $\mathrm{G} \mathrm{PD}_{\mathrm{EPS}}$ accounted for $3.24 \%$ and $2.77 \%$
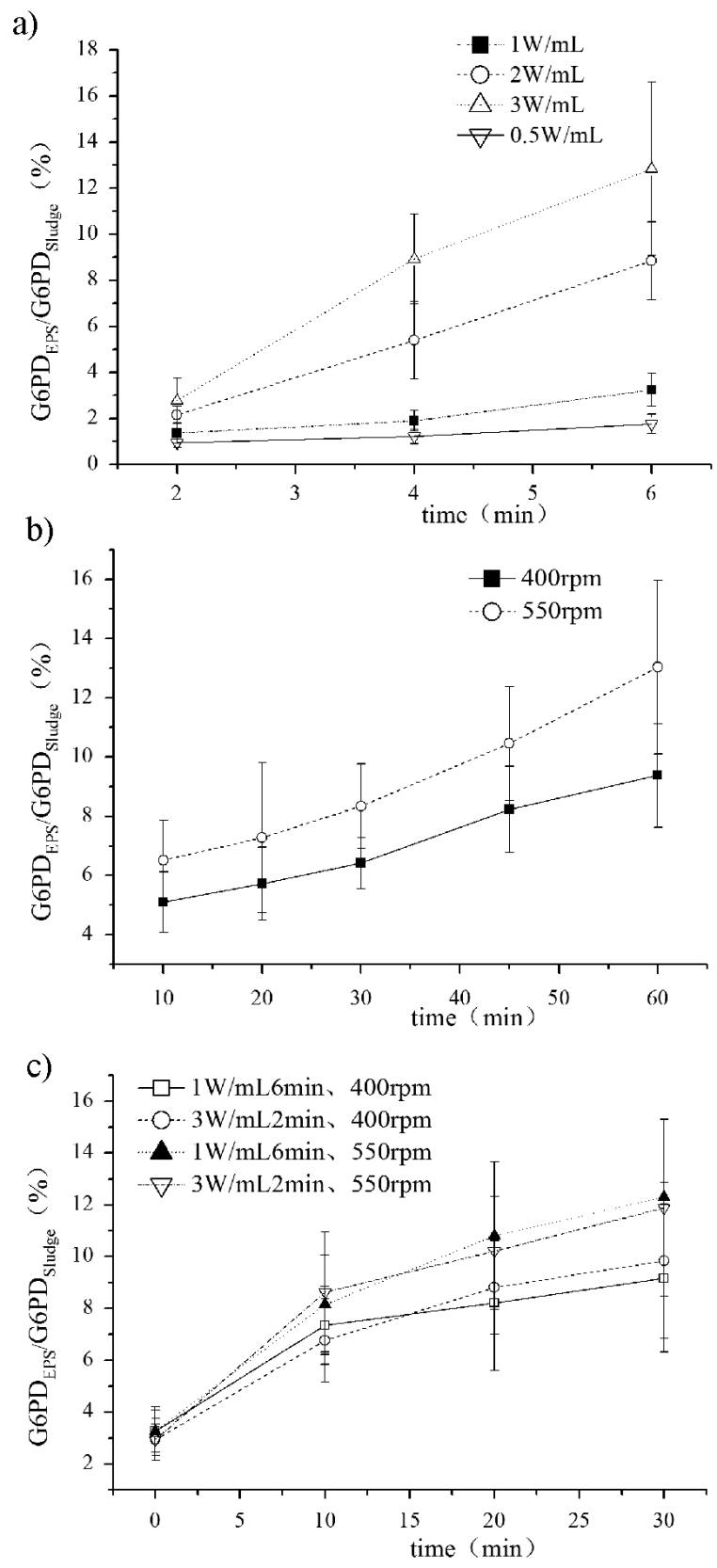

Fig. 1. G6PD activity in extracted EPS with different methods and conditions: a) G6PD activity in the extracted EPS with sonication method, b) G6PD activity in the extracted EPS with CER method, and c) G6PD activity in the extracted EPS with sonication-CER method.

$\mathrm{G} \mathrm{PD}_{\text {sludge }}$, respectively. Nevertheless, under conditions of sonication with a power density of $3 \mathrm{~W} / \mathrm{mL}$ for $6 \mathrm{~min}$, the $\mathrm{G}_{6 \mathrm{PD}}$ EPS accounted for $12.83 \%$ of $\mathrm{G} 6 \mathrm{PD}_{\text {sludge }}$. The acceptable range for the ratio of $\mathrm{G} \mathrm{PD}_{\mathrm{EPS}}$ to $\mathrm{G} 6 \mathrm{PD}_{\text {sludge }}$ was less than $10 \%$ [16]. Thereby, the extraction conditions of high power density $(\geq 3 \mathrm{~W} / \mathrm{mL})$ and long duration ( $\geq 6 \mathrm{~min}$ ) should not be used in the sonication method.

From Fig. 1b), with the increase of stirring rate and duration, the $\mathrm{G} \mathrm{PD}_{\mathrm{EPS}}$ was also increased. Under the conditions of CER with duration of $30 \mathrm{~min}$ and stirring 


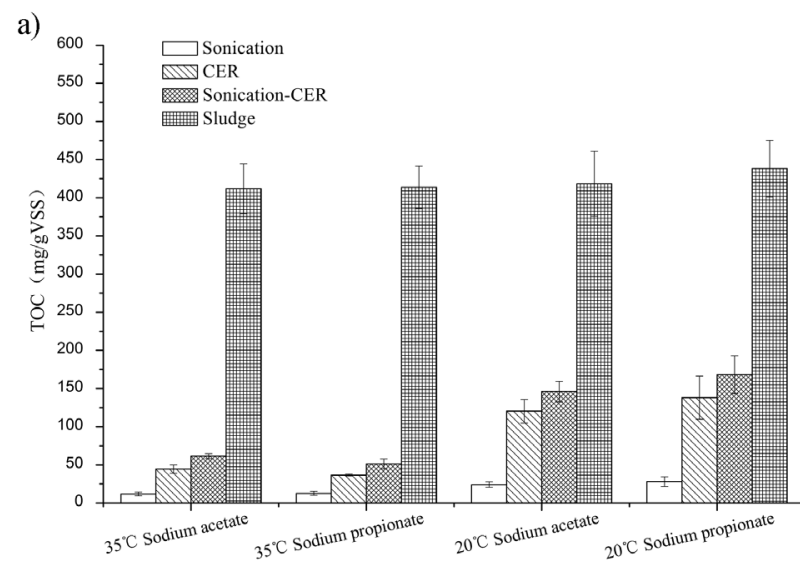

b)

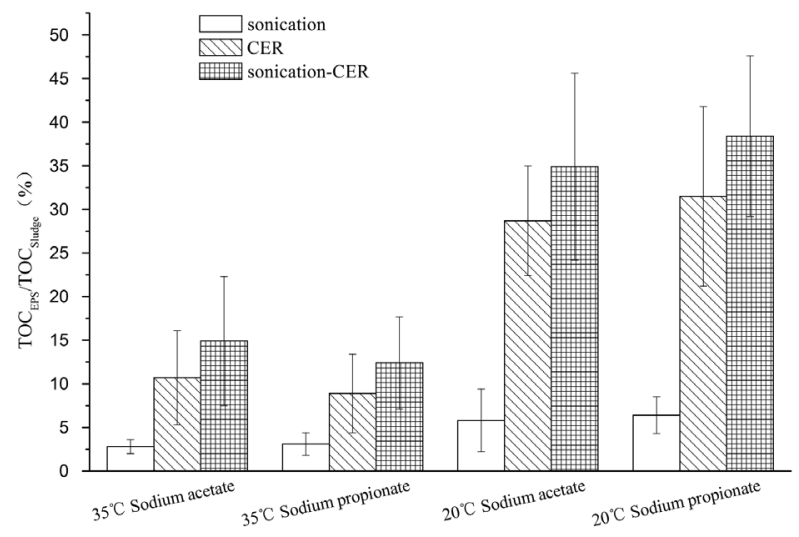

Fig. 2. Extraction amounts of EPS with different methods: a) $\mathrm{TOC}_{\mathrm{EPS}}$ and $\mathrm{TOC}_{\text {sludge }}$ and b) $\mathrm{TOC}_{\mathrm{EPS}} / \mathrm{TOC}_{\text {sludge }}$ ratio (the extraction condition of sonication method was the power density of $1 \mathrm{~W} / \mathrm{mL}$ for $6 \mathrm{~min}$; the extraction condition of CER method was the stirring rate of $400 \mathrm{rpm}$ for $30 \mathrm{~min}$; the extraction condition of sonication-CER method was the power density of $1 \mathrm{~W} / \mathrm{mL}$ for $6 \mathrm{~min}$ and the stirring rate of $400 \mathrm{rpm}$ for $30 \mathrm{~min}$ ).

rate of $400 \mathrm{rpm}$ and $550 \mathrm{rpm}$, the $\mathrm{G} \mathrm{PD}_{\mathrm{EPS}}$ accounted for $6.42 \%$ and $8.34 \%$ of $\mathrm{G}^{2} \mathrm{PD}_{\text {sludge }}$, respectively. Under conditions of CER with duration of $60 \mathrm{~min}$ and stirring rate of $400 \mathrm{rpm}$ and $550 \mathrm{rpm}$, the $\mathrm{G}_{6 \mathrm{PD}}$ EPS accounted for $9.38 \%$ and $13.04 \%$ of $\mathrm{G} \mathrm{PD}_{\text {sludge }}$, respectively. Thereby, the extracting conditions of high stirring rate $(\geq 550 \mathrm{rpm})$ and long duration $(\geq 60 \mathrm{~min})$ should not be employed in the CER method.

In the sonication-CER method, the sonication could disperse sludge flocs, and improve the reaction rate of the subsequent CER. From Fig. 1c), the risk of the cell lysis of sonication-CER method was more than the CER method. To avoid bacterial cell lysis, the suitable extracting conditions of sonication-CER method was sonication with the power density of $1 \mathrm{~W} / \mathrm{mL}$ for 6 min or the power density of $3 \mathrm{~W} / \mathrm{mL}$ for $2 \mathrm{~min}$, and subsequent CER reaction with the stirring rate of 400 rpm for $30 \mathrm{~min}$.

The bacterial cell apoptosis/death induced by extraction process was investigated (Fig. S2), with double-staining of Hoechst 33342/PI and observation by a confocal laser scanning microscope (CLSM).
The apparent bacterial cell apoptosis/death was not observed, of which the ratio of apoptosis/death cell to living cell was less than the corresponding ratio of $\mathrm{G} \mathrm{PD}_{\mathrm{EPS}}$-to-G6PD $\mathrm{Pludge}$. It might be due to cell membrane permeability increasing in the extraction process of the three methods, which caused G6PD transfer from bacterial cells to EPS, but the apoptosis/ death of bacterial cell was rarely induced. The results exhibited how cells lysis could be effectively avoided in the extraction process of the three methods.

\section{EPS Extraction Amount}

The temperature and matrix are important factors influencing biological metabolic activity and process and biological phosphorus removal performance [20, 21]. Compared to the sonication and CER methods, the extraction efficiencies of EPS and extracellular phosphorus with the sonication-CER method were studied, taking the activated sludge at the end of aerobic stage of the $4 \mathrm{~A} / \mathrm{O}-\mathrm{SBR}$ reactors as objects.

From Fig. 2, the extraction effects of EPS with the sonication-CER method were better than that with the sonication and CER methods. The extraction amounts of EPS with the sonication, CER and sonicationCER methods were 11.75 28.06 mg TOC/g VSS, $36.64 \sim 138.15 \mathrm{mg}$ TOC/g VSS, and 51.26 168.27 mg $\mathrm{TOC} / \mathrm{g} \mathrm{VSS}$, respectively, which were equivalent to $2.9 \sim 6.4 \%, 8.9 \sim 31.5 \%$, and $12.4 \sim 38.4 \%$ of $\mathrm{TOC}_{\text {sludge }}$. The sonication-CER method was the most efficient method in extracting EPS among the three.

For the sludge flocs of different temperature reactors, the extraction amount of EPS with the sonicationCER method were obviously different (Fig. 2). From Fig. 2, the extraction amounts of EPS of sludge flocs with sodium acetate and sodium propionate as the sole carbon source in $20^{\circ} \mathrm{C}$ were much greater than that in $35^{\circ} \mathrm{C}$. The extraction amount of EPS of sludge flocs from the $20^{\circ} \mathrm{C}$ sodium acetate, $20^{\circ} \mathrm{C}$ sodium propionate, $35^{\circ} \mathrm{C}$ sodium acetate, and $35^{\circ} \mathrm{C}$ sodium propionate reactors were $34.9 \%, 38.4 \%, 14.9 \%$ and $12.4 \%$ of $\mathrm{TOC}_{\text {sludge }}$, respectively. The results presented the reactor temperature as having an important influence on EPS content. The EPS content of activated sludge at the higher temperature $\left(35^{\circ} \mathrm{C}\right)$ was less than that at the lower temperature $\left(20^{\circ} \mathrm{C}\right)$, which could be explained as follows. Most EPS was biodegradable [22], and the net production of EPS was lower at the higher temperature $\left(35^{\circ} \mathrm{C}\right)$ because of the higher microbial metabolic activity. In addition, microbial communities were influenced by temperature, and the production of EPS of different microorganisms was distinctly different [5].

\section{Extraction Amount and Species of Extracellular Phosphorus}

As shown in Table 3 and Fig. 3, the extraction amounts of extracellular phosphorus with the sonication, CER, and sonication-CER methods were 
Table 3. ${ }^{31} \mathrm{P}$ NMR chemical shifts and relative peak areas of the extracted extracellular phosphorus in the different sludges with the different methods.

\begin{tabular}{|c|c|c|c|c|c|c|c|c|c|c|c|}
\hline \multirow{2}{*}{$\begin{array}{l}\text { Reactor } \\
\text { number }\end{array}$} & \multirow{2}{*}{$\begin{array}{l}\text { Extrac- } \\
\text { tion } \\
\text { methods }\end{array}$} & \multirow{2}{*}{$\begin{array}{l}\text { Extraction } \\
\text { amounts of } \\
\text { extracellular } \\
\text { phosphorus } \\
\text { (mg/gVSS) }\end{array}$} & \multicolumn{2}{|c|}{ OrthoP } & \multicolumn{2}{|c|}{ PyroP } & \multicolumn{2}{|c|}{$\begin{array}{l}\text { End groups of } \\
\text { PolyP } \\
\end{array}$} & \multicolumn{2}{|c|}{$\begin{array}{l}\text { Middle groups of } \\
\text { PolyP } \\
\end{array}$} & \multirow{2}{*}{$\begin{array}{c}\text { Average } \\
\text { chain } \\
\text { length } \\
\text { of polyP }\end{array}$} \\
\hline & & & $\begin{array}{c}\text { Chemical } \\
\text { shift } \\
(\mathrm{ppm})\end{array}$ & $\begin{array}{l}\text { Peak } \\
\text { area } \\
(\%)\end{array}$ & $\begin{array}{c}\text { Chemical } \\
\text { shift } \\
(\mathrm{ppm})\end{array}$ & $\begin{array}{c}\text { Peak } \\
\text { area } \\
(\%)\end{array}$ & $\begin{array}{c}\text { Chemical } \\
\text { shift } \\
(\mathrm{ppm})\end{array}$ & $\begin{array}{c}\text { Peak } \\
\text { area } \\
(\%)\end{array}$ & $\begin{array}{c}\text { Chemical } \\
\text { shift } \\
(\mathrm{ppm})\end{array}$ & $\begin{array}{c}\text { Peak } \\
\text { area } \\
(\%)\end{array}$ & \\
\hline \multirow{3}{*}{$1 \#$} & $\begin{array}{c}\text { Sonica- } \\
\text { tion }\end{array}$ & 1.55 & 5.34 & 96.72 & -5.73 & 1.13 & -- & 0 & -- & 0 & -- \\
\hline & CER & 27.00 & 5.39 & 86.71 & -5.54 & 6.60 & $\begin{array}{l}-4.83 \\
-4.99 \\
-5.07 \\
\end{array}$ & 2.08 & $\begin{array}{l}-19.47 \\
-20.18 \\
-21.49 \\
\end{array}$ & 4.08 & 5.92 \\
\hline & $\begin{array}{l}\text { Sonica- } \\
\text { tion-CER }\end{array}$ & 28.17 & 5.39 & 85.67 & -5.54 & 6.94 & $\begin{array}{l}-4.83 \\
-5.00 \\
-5.07 \\
\end{array}$ & 2.40 & $\begin{array}{l}-19.47 \\
-20.01 \\
-21.49 \\
\end{array}$ & 4.99 & 6.17 \\
\hline \multirow{3}{*}{$2 \#$} & $\begin{array}{l}\text { Sonica- } \\
\text { tion }\end{array}$ & 3.78 & 5.37 & 82.14 & -5.57 & 14.80 & $\begin{array}{l}-5.01 \\
-5.09\end{array}$ & 2.39 & $\begin{array}{l}-19.49 \\
-19.57 \\
-19.65\end{array}$ & 0.67 & 2.56 \\
\hline & CER & 29.29 & 5.36 & 63.77 & -5.57 & 16.73 & $\begin{array}{l}-4.84 \\
-5.01 \\
-5.08 \\
\end{array}$ & 3.11 & $\begin{array}{l}-19.49 \\
-20.02 \\
-21.50 \\
\end{array}$ & 16.39 & 12.53 \\
\hline & $\begin{array}{l}\text { Sonica- } \\
\text { tion-CER }\end{array}$ & 31.15 & 5.40 & 72.86 & -5.53 & 5.08 & -4.99 & 2.92 & $\begin{array}{l}-19.53 \\
-19.98 \\
-21.50 \\
\end{array}$ & 19.14 & 15.12 \\
\hline \multirow{3}{*}{$3 \#$} & $\begin{array}{l}\text { Sonica- } \\
\text { tion }\end{array}$ & 16.27 & 5.37 & 73.82 & -5.57 & 10.26 & $\begin{array}{l}-4.84 \\
-5.01 \\
-5.09\end{array}$ & 4.13 & $\begin{array}{l}-19.49 \\
-19.94 \\
-21.49\end{array}$ & 11.79 & 7.71 \\
\hline & CER & 58.37 & 5.16 & 60.81 & -- & 0 & -4.92 & 2.56 & $\begin{array}{l}-20.12 \\
-21.11 \\
-21.54 \\
\end{array}$ & 36.63 & 30.57 \\
\hline & $\begin{array}{l}\text { Sonica- } \\
\text { tion-CER }\end{array}$ & 66.99 & 5.14 & 48.34 & -5.67 & 0.47 & -4.92 & 2.84 & $\begin{array}{l}-20.10 \\
-21.08 \\
-21.53 \\
\end{array}$ & 47.39 & 35.33 \\
\hline \multirow{3}{*}{$4 \#$} & $\begin{array}{l}\text { Sonica- } \\
\text { tion }\end{array}$ & 14.97 & 5.30 & 87.27 & -- & 0 & -5.63 & 1.47 & -21.54 & 11.26 & 17.38 \\
\hline & CER & 66.53 & 5.39 & 64.76 & -5.51 & 4.60 & -4.98 & 2.67 & $\begin{array}{l}-19.50 \\
-20.07 \\
-21.49 \\
\end{array}$ & 27.97 & 22.94 \\
\hline & $\begin{array}{l}\text { Sonica- } \\
\text { tion-CER }\end{array}$ & 73.13 & 5.15 & 57.19 & -5.68 & 0.35 & -4.92 & 3.16 & $\begin{array}{l}-20.17 \\
-21.09 \\
-21.54\end{array}$ & 35.09 & 24.22 \\
\hline
\end{tabular}

a. $1 \#$ is $35^{\circ} \mathrm{C}$ sodium acetate reactor; $2 \#$ is $35^{\circ} \mathrm{Csodium}$ propionate reactor; $3 \#$ is $20^{\circ} \mathrm{C}$ sodium acetate reactor; $4 \#$ is $20^{\circ} \mathrm{C}$ sodium propionate reactor.

b. Conditions of the three extraction methods are the same as Fig. 2.

$1.55 \sim 16.27 \mathrm{mg} \mathrm{P} / \mathrm{g}$ VSS, 27.00 66.53 $\mathrm{mg} \mathrm{P} / \mathrm{g}$ VSS, and $28.17 \sim 73.13 \mathrm{mg} \mathrm{P} / \mathrm{g}$ VSS, respectively, which were equivalent to $3.3 \sim 17.1 \%$, 57.1 67.4\%, and $59.6 \sim 74.1 \%$ of $\mathrm{TP}_{\text {sludge }}$. The extraction amounts of extracellular phosphorus with the sonication-CER method and the CER method were comparative, which were greater than that of the sonication method. High valence cations were key substances for EPS adsorbing and combining phosphate or phosphate chemical precipitation in EPS $[23,24]$. Thereby extracellular phosphorus was released rapidly with the sonication-CER and CER methods, while high valence cations in sludge were exchanged with the sodium ion in CER. There are complex forces in EPS of activated sludge, including ionic bonds, hydrogen bonds and hydrophobic interactions [25]. Ionic bonds in EPS could be destroyed in the process of cation exchange reaction, but hydrogen bonds and hydrophobic interactions were less affected. Thus, the extraction efficiencies of extracellular phosphate with the sonication-CER and CER methods were greater than that of EPS.

The content of extracellular phosphorus in sludge flocs at different temperatures were obviously different. From Table 3, the extracellular phosphorus contents of 


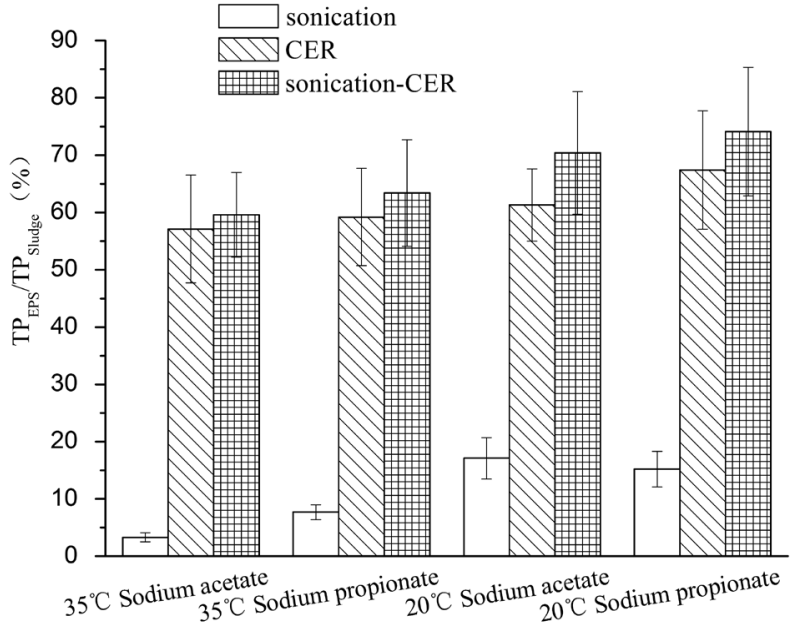

Fig. 3. $\mathrm{TP}_{\mathrm{EPS}} / \mathrm{TP}_{\text {sludge }}$ ratio with different methods (extraction conditions of the sonication, CER and sonication-CER methods were same as those in Fig. 2).

sludge flocs with sodium acetate or sodium propionate as a sole carbon source at $20^{\circ} \mathrm{C}$ were much greater than those at $35^{\circ} \mathrm{C}$. With the sonication-CER method, the extraction amounts of extracellular phosphorus of sludge flocs from the $20^{\circ} \mathrm{C}$ sodium acetate, $20^{\circ} \mathrm{C}$ sodium propionate, $35^{\circ} \mathrm{C}$ sodium acetate and $35^{\circ} \mathrm{C}$ sodium propionate reactors were $66.99 \mathrm{mg} \mathrm{P} / \mathrm{g}$ VSS, $73.13 \mathrm{mg} \mathrm{P} / \mathrm{g}$ VSS, $28.17 \mathrm{mg} \mathrm{P} / \mathrm{g}$ VSS and $31.15 \mathrm{mg} \mathrm{P} / \mathrm{g}$ VSS, respectively. Therefore, the temperature had an important influence on the extracellular phosphorus content of sludge floc.

The orthophosphate (orthoP) and polyP (including the end groups and middle groups of polyP) were the main species of extracellular phosphorus, which included a small amount of pyrophosphate (pyroP) and a very small amount of monoester and DNA phosphorus (Table 3). Importantly, the species of extracellular phosphate were affected by the temperature. There was a large amount of extracellular polyP in the $20^{\circ} \mathrm{C}$ sludge flocs, while orthoP was the major species of extracellular phosphorus in the $35^{\circ} \mathrm{C}$ sludge flocs. The extracted extracellular polyP of sludge flocs from the $20^{\circ} \mathrm{C}$ sodium acetate reactor with the sonication, CER and sonication-CER methods were $15.92 \%, 39.19 \%$, and $50.23 \%$ of $\mathrm{TP}_{\mathrm{EPS}}$, respectively, of which the polyP chain lengths were $7.71,30.57$, and 35.33 in turns. The extracted extracellular polyP of sludge flocs from the $35^{\circ} \mathrm{C}$ sodium acetate reactor with the above 3 methods were $0,6.16 \%$, and $7.39 \%$ of $\mathrm{TP}_{\mathrm{EPS}}$, respectively, of which the polyP chain lengths were $0,5.92$, and 6.17 in turns. In addition, their extracellular orthoP were $96.72 \%, 86.71 \%$, and $85.67 \%$ of $\mathrm{TP}_{\mathrm{EPS}}$, respectively. For the same sludge floc, the sonication-CER method could not only extract more extracellular phosphorus than the sonication method, but also extract more extracellular polyP. The loosely-bound EPS existing in the outer layer of sludge floc was extracted with the sonication method, through destroying the weak forces in sludge floc [26].

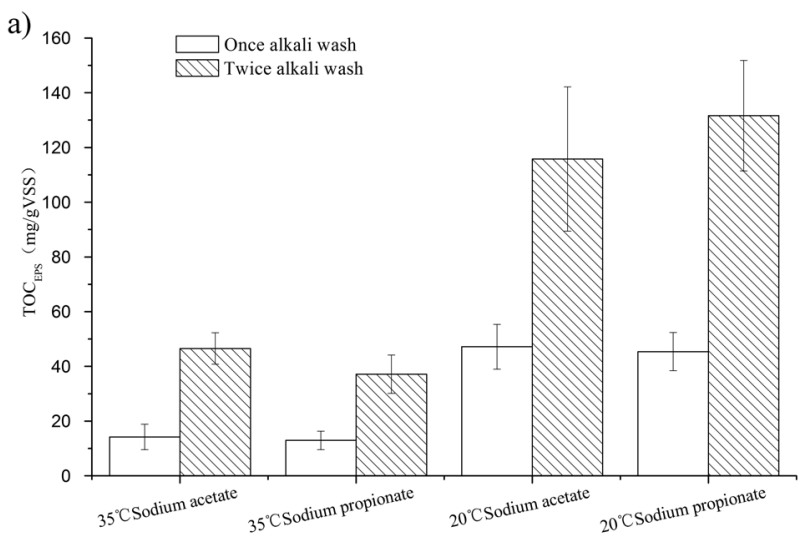

b)

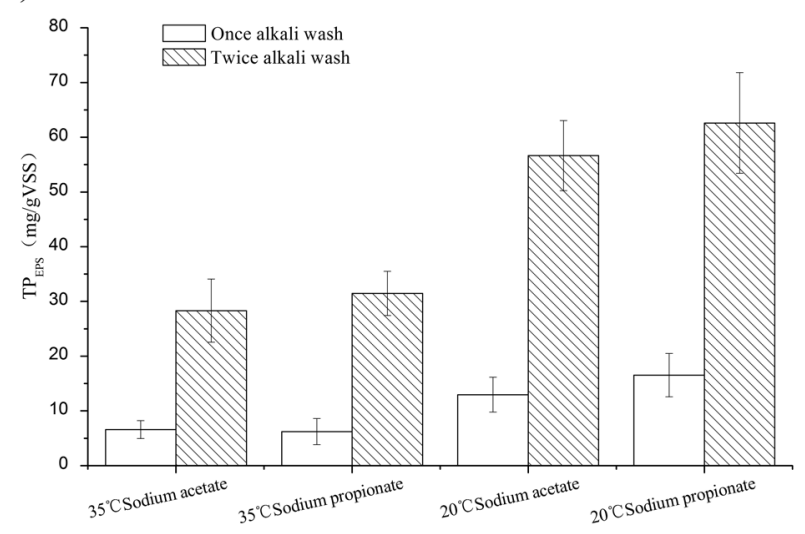

Fig. 4. Extraction amounts of EPS and extracellular phosphorus with CER by different wash procedures: a) extraction amounts of EPS and b) extraction amounts of extracellular phosphorus.

The tightly bound EPS located in an inner layer of sludge floc could be extracted with the subsequent CER method, based on the ion-exchange reaction and stirringshear action. Therefore, most of the extracellular polyP should be located in the inner layer of sludge floc.

\section{Relationships between Extracellular Phosphorus and Biological Phosphorus Removal Performance of Activated Sludge}

In this study, the extracellular phosphorus extracted by the sonication-CER and CER methods were up to $59.6 \sim 74.1 \%$ and $57.1 \sim 67.4 \%$ of $\mathrm{TP}_{\text {sludge }}$, respectively, which were slightly more than the results of Borovec et al. [4] and Wang et al. [8]. Importantly, the results in 2.2 section showed that massive cells lysis induced by the three extraction methods could be avoided, indicating that the phosphorus in sludge floc was mainly located in EPS, and that EPS was the storage of phosphorus. However, the results were markedly different from those reported Zhang et al. [10, 11] and Li et al. [9], in which the extracellular phosphorus extracted by CER method only accounted for 9.61 9.97\% and 6.6 10.5\% of $\mathrm{TP}_{\text {sludge }}$, respectively. The extraction efficiencies of EPS and their extracellular phosphorus with the CER method were affected by the washing procedure of 
a)

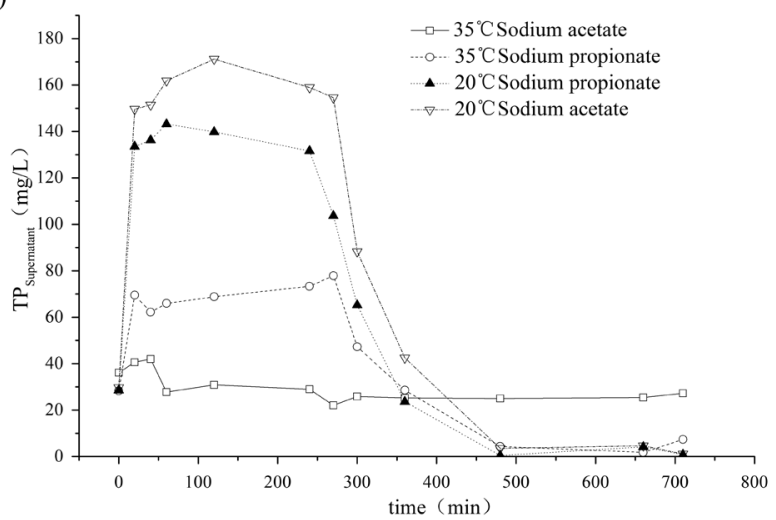

b)

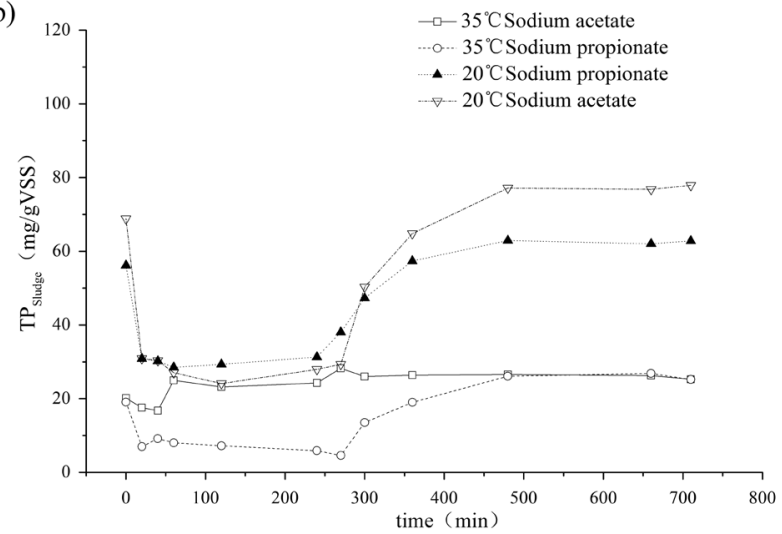

Fig. 5. Profiles of $\mathrm{TP}_{\text {supernatant }}$ and $\mathrm{TP}_{\text {sludge }}$ during the typical cycle: a) variation of $\mathrm{TP}_{\text {supernatant }}$ and $\mathrm{b}$ ) variation of $\mathrm{TP}_{\text {sludge }}$.

CER. From Fig. 4, the extracted amounts of EPS and their extracellular phosphorus by the CER method with two successive alkaline washes were greater than those with one alkaline wash, and the former were 2.5 3.3 and 3.8 5.1 times as much as the latter, respectively. In this study, the CER with two successive alkaline washes was adopted. Thereby the extracted amounts of extracellular phosphorus were more than those reported

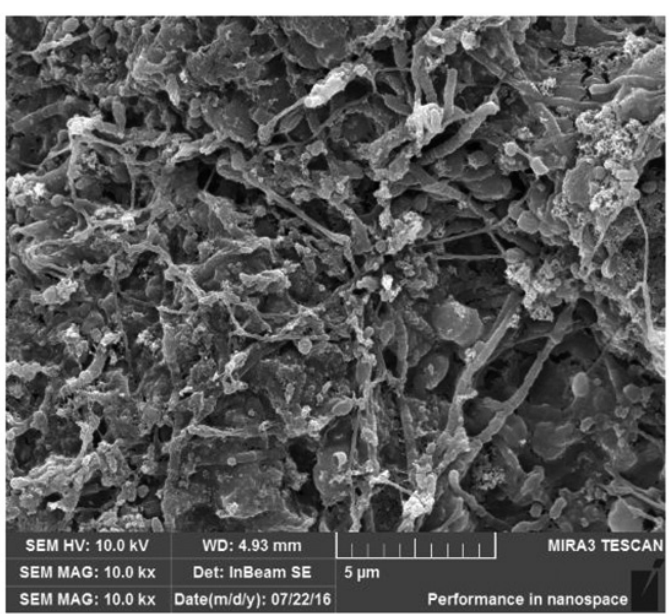

a

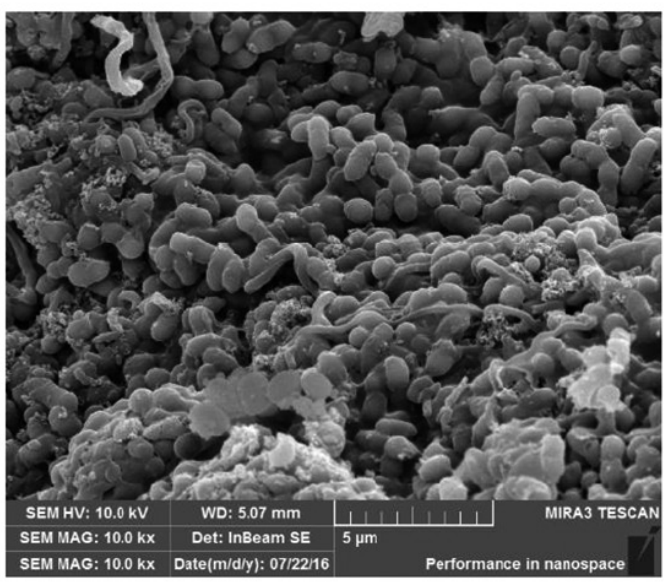

C

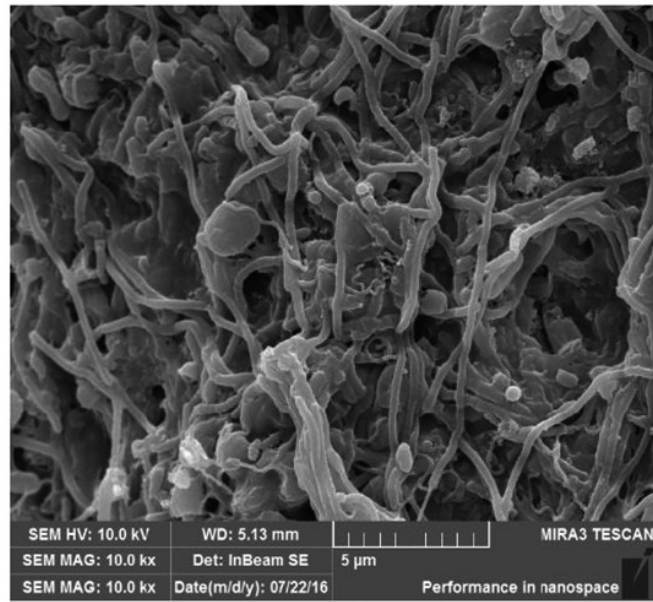

b

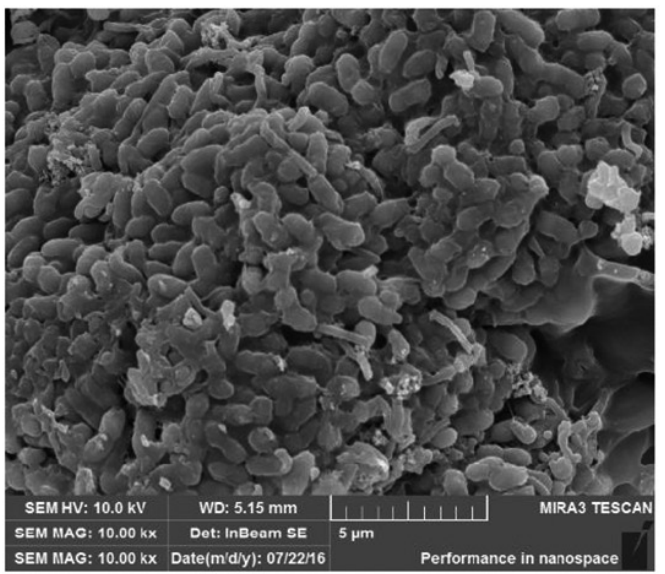

d

Fig. S3. Microbial morphology of the four reactors a) Microbial morphology of $35^{\circ} \mathrm{C}$ sodium acetate reactor; b) Microbial morphology of $35^{\circ} \mathrm{C}$ sodium propionate reactor; c) Microbial morphology of $20^{\circ} \mathrm{C}$ sodium acetate reactor; d) Microbial morphology of $20^{\circ} \mathrm{C}$ sodium propionate reactor. 
by the literature. All in all, the sonication-CER method using the CER with two successive alkaline washes is efficient for extracting extracellular phosphorus.

Temperature had an important influence on biological phosphorus removal [21, 27]. The biological phosphorus removal performances of the $4 \mathrm{~A} / \mathrm{O}-\mathrm{SBR}$ reactors were distinctly different (Fig. 5). From Fig. 5, the effluent TP concentrations of the $20^{\circ} \mathrm{C}$ reactors fed with sodium acetate or sodium propionate were lower than those of the $35 \mathrm{~V}$ reactors. Furthermore, the amounts and speeds of both anaerobic phosphorus release and aerobic phosphorus uptake in the $20^{\circ} \mathrm{C}$ reactors were greater than those of the $35^{\circ} \mathrm{C}$ reactors. The orders of the biological phosphorus removal performance of the 4 reactors were as follows: $20^{\circ} \mathrm{C}$ sodium acetate reactor $>20^{\circ} \mathrm{C}$ sodium propionate reactor $>35^{\circ} \mathrm{C}$ sodium propionate reactor $>35^{\circ} \mathrm{C}$ sodium acetate reactor. From Table 3, the extracellular phosphorus contents and the extracellular polyP contents of the sludge in the $20^{\circ} \mathrm{C}$ reactors were also greater than those of the sludge in the $35^{\circ} \mathrm{C}$ reactors. In addition, the orders of the extracellular polyP content of the sludge in the 4 reactors were also as follows: $20^{\circ} \mathrm{C}$ sodium acetate reactor $>20^{\circ} \mathrm{C}$ sodium propionate reactor $>35^{\circ} \mathrm{C}$ sodium propionate reactor $>35^{\circ} \mathrm{C}$ sodium acetate reactor. The results revealed that there should be a close relationship between the content and species of extracellular phosphorus and the biological phosphorus removal performance of activated sludge.

Phosphorus accumulating organisms (PAOs) are the key functional microorganism in EBPR, which play an important role in biological phosphorus removal [28]. From Fig. S3, the main microorganisms in the sludge of the two $20^{\circ} \mathrm{C}$ reactors were Brevibacteria, which were common PAOs [29]. However, there were almost no Brevibacteria in the sludge of the two $35^{\circ} \mathrm{C}$ reactors. The relationship between the content and species of extracellular phosphorus and the biological phosphorus removal performance of activated sludge might be linked to the microbial population. Thereby, the relationship between microbial population and the content and species of extracellular phosphorus is in need of further elucidation.

\section{Conclusions}

The sonication-CER method was an efficient and reliable method for extracting EPS and extracellular phosphorus, which could avoid the decomposition of extracellular polyP and the massive lysis of bacteria cells. In the sonication-CER method, employing CER with two successive alkaline washes was a key factor for efficiently extracting extracellular phosphorus. The extracellular phosphorus content of aerobic activated sludge in $4 \mathrm{~A} / \mathrm{O}-\mathrm{SBR}$ reactors was up to 59.6 74.1\% $\mathrm{TP}_{\text {sludge }}$, which suggested that the phosphorus in the sludge floc were mainly located in EPS. Furthermore, polyP was the main species of extracellular phosphorus in the EBPR sludge, mainly existing in the inner layer of sludge floc. The extracellular phosphorus contents and the extracellular polyP contents of the sludge with EBPR performance in the $20^{\circ} \mathrm{C}$ reactors were greater than those of the sludge without EBPR performance in the $35^{\circ} \mathrm{C}$ reactors. There was a close relationship between the content and species of extracellular phosphorus and the EBPR performance of activated sludge.

\section{Acknowledgements}

This work was supported by the National Natural Science Foundation of China under grant No. 21577174 and the Chongqing Basic Science and Advanced Technology Research under grant Nos. CSTC2015jcyjA20012, CSTC2014jcyjA20004 and CSTC2015jсуjB0390.

\section{Conflict of Interest}

The authors declare no conflict of interest.

\section{References}

1. OEHMEN A., LEMOS P.C., CARVALHO G., YUAN Z., KELLER J., BLACKALL L.L., REIS M.A. Advances in enhanced biological phosphorus removal: From micro to macro scale. Water Res, 41 (11), 2271, 2007.

2. LANHAM A.B., OEHMEN A., SAUNDERS A.M., CARVALHO G., NIELSEN P.H., MAM Reis. Metabolic modelling of full-scale enhanced biological phosphorus removal sludge. Water Res, 66, 283, 2014.

3. ZHENG X.L., SUN PEIDE., HAN J.Y., SONG Y.Q, HU Z.R., FAN H.Q., LV S.Y. Inhibitory factors affecting the process of enhanced biological phosphorus removal (EBPR) - A mini-review. Process Biochem., 49 (12), 2207, 2014.

4. BOROVEC J., SIROVÁ D., MOŠNEROVÁ P., REJMÁNKOVÁ E., VRBA J. Spatial and temporal changes in phosphorus partitioning within a freshwater cyanobacterial mat community. Biogeochemistry, 101 (1-3), 323, 2010.

5. WANG H.W., DENG H.H., MA L.M., GE L.Y. Influence of operating conditions on extracellular polymeric substances and surface properties of sludge flocs. Carbohydr. Polym., 92 (1), 510, 2013.

6. LI D., LV Y., ZENG H., ZHANG J. Enhanced biological phosphorus removal using granules in continuous-flow reactor. Chem. Eng. J., 298, 107, 2016.

7. CLOETE T.E., OOSTHUIZEN D.J. The role of extracellular exoploymers in the removal of phosphorus from activated sludge. Water Res., 35 (15), 3595, 2001.

8. WANG R., PENG Y., CHENG Z., REN N. Understanding the role of extracellular polymeric substances in an enhanced biological phosphorus removal granular sludge system, Bioresour. Technol., 169 (5), 307, 2014.

9. LI N., REN N.Q., WANG X.H., KANG H. Effect of temperature on intracellular phosphorus absorption and extra-cellular phosphorus removal in EBPR process. Bioresour. Technol., 101 (15), 6265, 2010. 
10. ZHANG H.L., FANG W., WANG Y.P., SHENG G.P., XIA C.W., ZENG R.J., YU H.Q. Species of phosphorus in the extracellular polymeric substances of EBPR sludge. Bioresour. Technol., 142 (8), 714, 2013a.

11. ZHANG H.L., FANG W., WANG Y.P., SHENG G.P., ZENG R.J., LI W.W., YU H.Q. Phosphorus Removal in an Enhanced Biological Phosphorus Removal Process: Roles of Extracellular Polymeric Substances. Environ. Sci. Technol., 47 (20), 11482, 2013b.

12. ZHANG Z.C., HUANG X., YANG H.J., XIAO K., LUO X., SHA H., CHEN Y.M. Study on P forms in extracellular polymeric substances in enhanced biological phosphorus removal sludge by 31P-NMR spectroscopy. Spectroscopy and Spectral Analysis, 29 (2), 536, 2009.

13. JIA F.X., YANG Q., HAN J.H., LIU X.H., LI X.Y., PENG Y.Z. Modeling optimization and evaluation of tightly bound extracellular polymeric substances extraction by sonication. Applied Microbiology and Biotechnology, 100 (19), 1, 2016.

14. LI N., SATOH H., MINO T. Dynamics of dewaterability and bacterial populations in activated sludge. Water Sci. Technol., 66 (8), 1634, 2012.

15. CLOCK G.E. Further studies on the properties and assay of glucose-6-phosphogluconate dehydrogenase of rat liver. Biochem.J., 55, 400, 1953.

16. FRØLUND B., PALMGREN R., KEIDING K., NIELSEN $\mathrm{H}$. Extraction of extracellular polymers from activated sludge using a cation exchange resin. Water Res., 30 (8), 1749, 1996.

17. TURNER B.L., MAHIEU N., CONDRON L.M. Phosphorus-31 nuclear magnetic resonance spectral assignments of phosphorus compounds in soil $\mathrm{NaOH}$ extracts. Soil Science Society of America Journal, 67 (2), 497, 2003.

18. APHA. Standard Methods for the Examination of Water and Wastewater, $20^{\text {th }}$ ed. American Public Health Association, American Water Works Association, Water Pollution Control Federation, Washington, D.C., 2540, 1998.

19. TURNER B.L. Optimizing phosphorus characterization in animal manures by solution phosphorus-31 nuclear magnetic resonance spectroscopy. J. Environ. Qual., 33 (2), 757, 2004.
20. CHEN X., YUAN L.J., LV J.H., NIE K. Influence of temperature on sludge settleability and bacterial community structure in enhanced biological phosphorus removal systems. Desalin Water Treat., 57 (21), 9900 , 2016.

21. KEE F.L., TADASHI S., YING H.O., ADELINE S.M.C., HAK K.Y., PEI Y.Ho. Kinetic and stoichiometric characterization for efficient enhanced biological phosphorus removal (EBPR) process at high temperatures. Bioprocess Biosyst Eng., 38 (4), 729, 2015.

22. ZHANG X.Q., BISHOP P.L. Biodegradability of biofilm extracellular polymeric substances. Chemosphere, 50 (1), 63, 2003.

23. SHENG G.P., ZHANG M.L., YU H.Q. Characterization of adsorption properties of extracellular polymeric substances (EPS) extracted from sludge. Colloids. Surf. B. Biointerfaces, 62 (1), 83, 2008.

24. AYSE G.G., BAŞAK K., FERHAN Ç. Extracellular polymeric substances (EPS) and surface properties of activated sludges: effect of organic carbon sources. Environ. Sci. Pollut. Res., 23 (2), 1, 2015.

25. LIAO B.Q., ALLEN D.G., DROPPO G., LEPPARD G.G., LISS S.N. Surface properties of sludge and their role in bioflocculation and settleability. Water Res., 35 (2), 339, 2001.

26. HAN X.M., WANG Z.W., ZHU C.W., WU Z.C. Effect of ultrasonic power density on extracting loosely bound and tightly bound extracellular polymeric substances. Desalination, 329 (18), 35, 2013.

27. SAYI-UCAR N., SARIOGLU M., INSEL G., COKGOR E.U., ORHON D., LOOSDRECHT VAN M.C.M. Longterm study on the impact of temperature on enhanced biological phosphorus and nitrogen removal in membrane bioreactor. Water Res., 84, 8, 2015.

28. WANG R.Y., LI Y.M., CHEN W.L., ZOU J.T., CHEN Y.G. Phosphate release involving PAOs activity during anaerobic fermentation of EBPR sludge and the extension of ADM1. Chem. Eng. J., 287, 436, 2016.

29. GREGORY R.C., PHILIP H., PHILIP L.B., ANDREW S., JÜRG K., DAVID J., LINDA L.B. Identification of Polyphosphate-Accumulating Organisms and Design of 16S rRNA-Directed Probes for Their Detection and Quantitation. Appl. Environ.Microbiol., 66 (3), 1175, 2000. 